\title{
Church Growth in Times of Secularization: A Case Study of People Joining Evangelical Congregations in the Netherlands
}

\author{
Paul Vermeer $^{1}$ (D) $\cdot$ Peer Scheepers ${ }^{2}$
}

Received: 10 March 2020 / Accepted: 22 October 2020 / Published online: 13 November 2020

(c) The Author(s) 2020

\begin{abstract}
Background: Today the Dutch religious landscape is characterized by two opposite trends. On the one hand, there is a massive and dominant trend of religious disaffiliation which mostly affects the Roman Catholic Church and the mainline Protestant churches, while on the other hand the Netherlands also witnesses the emergence of several independent, evangelical congregations of near megachurch size. Purpose: Against the background of these opposite trends, this paper focuses on the second trend and tries to explain why some people join an evangelical congregation. Methods: For this purpose, quantitative data gathered among the audiences of six thriving evangelical congregations are analyzed in view of the following research questions: (1) What was the previous religious affiliation of the people who switched or converted to one of the six participating evangelical congregations? and (2) Which factors induced the switch or conversion to these congregations? Results: Results of bivariate and multivariate analyses show that these congregations attract both mainline and orthodox Protestant switchers as well as a significant number of secular converts, whose decision to join these evangelical congregations is induced by early socialization experiences, their intrinsic religious orientation and the switching of their partner. Closer scrutiny into the background of the apparent secular converts reveals, however, that several of these converts are probably re-affiliates. Although these secular converts indicated to be a religious none in their early teens, their conversion to evangelicalism is in part still induced by certain, early religious socialization experiences. Conclusions and Implications: This insight puts the alleged success of these evangelical congregations in more perspective. It shows that their success is more a matter of circulating, religious believers and not so much a matter of successfully reaching out to the unchurched. In all likelihood, then, thriving evangelical congregations will remain an exception in secular societies like the Netherlands and evangelical church growth in no way marks a break with the ongoing trend of religious disaffiliation.
\end{abstract}

Keywords Church growth · Evangelicalism · Switching · Conversion · The Netherlands

Extended author information available on the last page of the article 


\section{Introduction}

The Netherlands is one of the world's leading countries in terms of secularization, with religious communities losing believing and practicing members on a large scale over recent decades (De Hart and Van Houwelingen 2018, 21-26; Reitsma et al. 2012). While in 1966 still 67 per cent of the Dutch population reported to be a member of one of the many Christian churches in the country, by 2015 this figure had dropped to 25 percent. But not only church membership as such has decreased, church members have also become less committed to their religious congregation. In 1966 still 50 per cent of Dutch church members attended church on a weekly basis, but by 2015 the proportion of regular attendees among church members had dropped to 12 per cent (Bernts and Berghuijs 2016, 23-25; Kregting et al. 2018). Dutch Christian churches thus have gradually lost membership as well as commitment. But although secularization is the dominant trend in the Netherlands, there are notable exceptions.

To begin with, the Dutch religious landscape is very diverse and the aforementioned developments especially affect mainline churches like the Roman Catholic Church and the Protestant Church in the Netherlands. Other, mostly smaller and more orthodox Protestant churches, like the Christian Reformed Church or the Free Reformed Church, are less affected by secularization and have remained fairly stable over time or have even experienced growth instead of decline during the past decades (Becker and De Hart 2006, 30-31; De Hart and Van Houwelingen 2018, 36-37). This is probably due to the fact, that these specific Reformed groups for the most part still live together in close-knit, religiously homogeneous communities, the so-called Dutch Bible belt, which enables them to uphold a supporting religious plausibility structure. ${ }^{1}$

Secondly, next to these stable orthodox Protestant churches, the Netherlands nowadays also witnesses the emergence of several independent congregations, or free churches, that may be labelled evangelical. In part these evangelical congregations can be found in the Dutch Bible belt, but they are also present in parts of the Protestant north of the country that have been affected by secularization as much as the traditionally, Catholic south. Moreover, today these independent evangelical congregations can even be found in secular, urban centers like in the

\footnotetext{
1 The Dutch Christian religious landscape consists of various churches and independent congregations. The largest Christian church is the Roman Catholic Church followed by the Protestant Church in the Netherlands. This latter church resulted from a merger in 2004 between three more mainline Protestant churches: the Dutch Reformed Church, the Reformed Church and the Evangelical-Lutheran Church. However, the collective noun 'Reformed' does not refer to a single church, but refers to various groups that separated from the Dutch Reformed Church during the nineteenth century. The Reformed churches that did not merge into the Protestant Church of the Netherlands in 2004 and thus stayed independent, like the Christian Reformed Church or the Free Reformed Church, are considered more orthodox. Today, there exist approximately ten different Reformed churches in the Netherlands mostly located in the Dutch Bible belt. Next to these churches, the Dutch Christian religious landscape also consists of several independent Pentecostal and evangelical congregations as well as very liberal groups like the Mennonites and the Remonstrant Church. Especially the membership of these more liberal groups has decreased significantly during the last decades.
} 
cities of Amsterdam and Rotterdam. The emergence of these independent congregations is also not typically Dutch. Similar developments are present in, for instance, Germany where mainline churches face decline and free churches, like charismatic, Pentecostal and evangelical congregations, have remained stable or have also experienced growth (Pollack and Rosta 2015, 115-116). Moreover, in a recent report on religion and secularism in Europe (Sägesser et al. 2018), it is stated that this rise of free churches, and especially Pentecostal and evangelical congregations, is becoming visible in various European countries and is currently resulting in the emergence of evangelical megachurches in the UK, Germany and the Netherlands.

Against the background of these current developments in the Dutch and European religious landscape, this paper delves more deeply into the phenomenon of evangelical church growth in the Netherlands. For this purpose, we focus on six thriving evangelical congregations and wonder where the people came from who deliberately choose to join one of these congregations. Thus we aim to offer a partial and tentative explanation for why people join evangelical congregations in the context of Dutch secular society. In view of this aim, we address the following research questions: (1) What was the previous religious affiliation of the people who switched or converted to one of the six participating evangelical congregations? and (2) Which factors induced the switch or conversion to these congregations? However, addressing these questions does not mean, that we consider evangelical church growth to be a counter-indication for secularization. Evangelicals constitute a small minority group in the Netherlands-a rough estimate is that they do not make up more than 1.0 per cent of the Dutch population (Bernts et al. 2006, 105-108) — and the growth of a few evangelical congregations in no way compensates the loss of membership mainline Christian churches suffer. In this respect, Dutch evangelical congregations find themselves in a completely different context than evangelical congregations in, for instance, the US where nondenominational evangelicalism is nowadays the largest expression of Protestantism in American society (cf. for instance Putnam and Campbell 2010, 100-108; Stark 2015, 192-196). But it is precisely this overall context of massive secularization, which makes it interesting to study exceptions. That is to say, studying evangelical church growth in the context of the Netherlands may yield new insights into the way more marginal religious communities persist in a largely secular society.

Before we continue by presenting our theoretical framework, one final remark is in place here. Since our research questions require that we have a substantial number of switchers and converts in our sample, we specifically targeted the audiences of a limited number of large and thriving evangelical congregations. This means that our sample is not representative for the total population of Dutch evangelicals and so we cannot generalize our findings to Dutch evangelicals as such. Our study is a case study into six specific, i.e. thriving, evangelical congregations. It is not a study into Dutch evangelicalism as such nor do we claim that all evangelical congregations are large and thriving or that the overall number of evangelicals is increasing in the Netherlands. 


\section{Derivation of Hypotheses}

In view of our first research question, we commence by considering the possible sources of evangelical church growth. Thus we wonder where the people who joined these six thriving evangelical congregations possibly came from. Since evangelicalism is firmly rooted in Christian orthodoxy and is often depicted in the Netherlands as a conservative and reactionary movement (Boersema 2005, 169), Kelley's (1972) "strict church" theory, which suggests that conservative churches grow at the expense of more liberal, mainline churches, may be a helpful starting point in this respect. The basic idea is that the lenient and moderate faith of mainline churches no longer satisfies the religious needs of its constituency who, therefore, switch to more demanding churches. This notion may be elaborated further with the help of the so-called "ecological niche" perspective (Sherkat 2001; cf. also Loveland 2003, 150). Following this ecological niche perspective, mainline churches lack sufficient distinctiveness from secular culture and organizations, because they too much embrace secular values and outlooks (cf. also McGrath 1995, 90-93). As a result, people with stronger religious needs drop out of church altogether or they turn to more distinctive and demanding churches, whereas people from more distinct churches are far less likely to switch. However, religious switching is constrained in an important way, i.e. people tend to switch to similar churches. As Sherkat and Wilson $(1995,1016)$ point out, religious switching is not only an individual choice; it is also affected by how others, spouses, friends or relatives, would react to it, as anticipated by the potential switcher. Therefore, switching to very dissimilar churches, which relevant others are likely to reject, is highly unlikely. The greater the cultural and theological distance between one's religious affiliation of origin and a potentially new religious congregation, the less likely it is for people to actually switch to this new religious congregation, as, for example, Bibby's (1999) research among Canadians clearly showed. Furthermore, as Iannaccone (1990; cf. also Need and De Graaf 2005, 291) claims, people are also less likely to switch to very dissimilar churches, because this makes the religious human capital they accumulated worthless. That is to say, throughout their lives people have become familiar with rituals, creeds, myths, symbols and the like of a specific religious tradition and tend to switch to churches in which their religious human capital is still valuable or useful. Otherwise, switching reduces religious human capital and thus becomes more costly than staying.

Now, as we already mentioned in the introduction, in the Netherlands most orthodox Protestant churches are primarily located in specific areas, the Dutch Bible belt, and indeed constitute a sort of ecological niche. As a consequence, orthodox Protestant churches are more distinctive from secular culture than mainline Protestant churches or the Roman Catholic Church, which inhibits the switching of their members to an evangelical congregation. In addition, when it comes to cultural and theological differences, the distance between evangelicalism and Catholicism is far greater than the distance between evangelicalism and mainline and orthodox Protestantism. This presumably makes the switching of Catholics to an evangelical congregation costly and thus rare. Finally, since religious 
disaffiliation is massive in the Netherlands and conversion exceptional (Need and De Graaf 2005, 295-296; cf. also Kregting et al. 2018), it is also unlikely that evangelical congregations will attract a lot of secular converts. Together these considerations result in the following expectations regarding the sources of evangelical church growth in the Netherlands: People joining evangelical congregations are more likely to have a mainline Protestant background than an orthodox Protestant, a Catholic or a secular background (hypothesis 1).

But why would people join an evangelical congregation in the first place? This is our second research question, which we address by considering three sets of explanations for religious switching often mentioned in scholarly literature; i.e. factors concerning an individual's religious socialization, his or her religious orientation and aspects of his or her socio-religious network.

As religious socialization research has time and again revealed, being raised in a religious way by religiously committed parents is an important predictor for juvenile religious commitment, which, in turn, is an important predictor for adult religious commitment (Myers 1996; Vermeer, Janssen and De Hart 2011). But, as mostly US research reveals, religious socialization also negatively affects religious switching. Powerful religious socialization experiences during adolescence solidify one's ties to a particular religious congregation, which decreases the likelihood of religious switching in later life (Hadaway and Marler 1993, 111; Sherkat and Wilson 1995, 996-997). As a consequence, people with less powerful religious socialization experiences, which may be apparent, for instance, by lower rates of juvenile church attendance, are more likely to switch to another congregation or to abandon religion altogether (Sherkat 1991, 175).

However, we have reason to assume that these US findings may not directly apply to the specific case of switching to evangelical congregations in the Netherlands. As mentioned already, religious disaffiliation is widespread in the Netherlands and religious switching is rare, i.e., most Dutch stay in the church they were raised in or abandon church altogether (Becker and De Hart 2006, 40; cf also Need and De Graaf 2005). Furthermore, despite their emphasis on individual conversion and the personal appropriation of faith, which certainly fits the present-day Dutch cultural climate (Hak 2006, 101-104), evangelical congregations also exhibit features of a conservative, reactionary movement due to their view on the authority of the Bible or their position regarding contemporary moral issues like abortion, euthanasia or homosexuality (Boersema 2005, 169; Vermeer \& Scheepers 2018). In the context of the Dutch religious landscape evangelical congregations thus represent a more distinctive and demanding form of Christianity. Given this specific Dutch context, then, we would suppose that switching to an evangelical congregation is a deliberate choice made by people who have been thoroughly, and not just superficially, socialized in a specific Christian church. In addition, religious socialization occurs for most Dutch in the context of the family, since Dutch secular society hardly constitutes a social environment supportive of acquiring a religious identity (Kelley and De Graaf 1997). So, it all comes down to parents who raise their children in a religious way by performing religious practices at home, taking their children to church or sending them to a religious school and not to one of the many public schools. Therefore, contrary to what the aforementioned US research suggests, we expect 
that especially people who have been thoroughly socialized in an overt, religious family climate will join an evangelical congregation. Thus our second hypothesis reads: Individuals are more likely to join an evangelical congregation if they previously enjoyed a thorough religious socialization, which implies that they: have been raised in a religious way by their parents (hypothesis $2 \mathrm{a}$ ), have parents who considered their religious upbringing very important (hypothesis $2 \mathrm{~b}$ ), have parents who regularly attended church (hypothesis 2c), grew up in families where prayer (hypothesis $2 \mathrm{~d}$ ) and Bible reading were regular activities (hypothesis $2 \mathrm{e}$ ), attended church regularly as youths (hypothesis $2 \mathrm{f}$ ) and attended a religious school (hypothesis $2 \mathrm{~g}$ ).

Another socialization experience, next to being explicitly raised in a religious way, may affect switching as well. US research has shown that the child's identification with a specific congregation may be hampered by heterogeneous affiliation patterns in the family. If parents do not share the same religious affiliation, it becomes more difficult for the child to develop strong ties with a particular religious congregation, which thus increases the likelihood of religious switching in later life (Bibby 1999, 160; Hadaway and Marler 1993, 108, 111; Sherkat 1991, 173; Sherkat and Wilson 1995, 999). We propose to test this insight also in the Dutch situation and so we expect that: Individuals are more likely to join an evangelical congregation if they have been raised in a religiously heterogeneous family (hypothesis 3).

Next to specific juvenile socialization experiences, we propose that joining an evangelical congregation may also relate to specific individual, religious characteristics. In this respect, we especially assume that religious orientation may be significant. A common idea underlying much research into religious switching is that switchers tend to be more religious than stayers (Hadaway 1980, 452; Sherkat and Wilson 1995, 997). Switching, and especially switching to more conservative and countercultural churches, is seen as a deliberate choice, which is informed by an intrinsic religious motivation, an insight which also relates to the "ecological niche" perspective mentioned earlier. People switching to more conservative churches desire more otherworldly religious compensators, according to Sherkat (2001, 1486), which is why they look for more religiously distinctive congregations. Therefore, people switching to more conservative congregations are more likely to be motivated by intrinsic religious concerns than by more mundane, extrinsic considerations. That is to say, for them religion is not something that primarily serves other ends, such as social standing or building networks, but something of intrinsic value and meaning, which pervades their entire life (Batson and Ventis 1982, 137-170). Furthermore, as Chorpade et al. (2010) have shown, having an intrinsic religious orientation is also positively related to endorsing traditional Christian doctrines, which again supports the idea that having such a specific religious orientation may be a powerful incentive for joining an evangelical congregation. These considerations result in the following expectations: Individuals are more likely to join an evangelical congregation if they display an intrinsic religious orientation (hypothesis 4a) and are less likely to join an evangelical congregation if they display an extrinsic religious orientation (hypothesis 4 b).

Finally, people may also join an evangelical congregation for reasons related to their socio-religious network. Above, following the study of Sherkat and 
Wilson (1995), we already mentioned that conversion and religious switching is also affected by the way people closely related to the convert or switcher, like parents, relatives or friends, react to these instances of religious mobility. Furthermore, since children are known to adopt the convictions and behaviors of significant others, i.e. mostly their parents (Myers 1996; Vermeer et al. 2011), we may also assume that if parents themselves converted or switched to an evangelical congregation, children will follow in their footsteps and will convert or switch to an evangelical congregation as well. Or, conversely, the conversion or switching of the child may affect the conversion or switching of the parents. Whatever the causal order here, we thus assume that there may be a close connection between the conversion or switching of the child and the conversion or switching of the parents. Our next hypothesis, therefore, reads: Individuals are more likely to join an evangelical congregation if they have parents who switched or converted to an evangelical congregation as well (hypothesis 5).

When it comes to religious mobility, socio-religious network factors not only relate to parents, relatives or friends but also, and even more so, to the partner. A factor often referred to as being important for religious switching is having a partner who was raised in a different religious tradition (Hadaway and Marler 1993, 108; Loveland 2003, 154; Need and De Graaf 2005, 296; Sherkat and Wilson 1995, 1000). Switching, then, can be a way of making a relationship more homogeneous (Sandomirsky and Wilson 1990, 1215), since partners tend to switch toward congruence (Hadaway and Marler 1993, 99). This insight results in our final hypothesis: Individuals are more likely to join an evangelical congregation if they have a partner who switched or converted to an evangelical congregation as well (hypothesis $6)$.

By testing these hypotheses we do not only consider the sources of growth of the six evangelical congregations participating in our study (hypothesis 1), but we also try to explain why the respondents involved actually joined these congregations (hypotheses 2-6). In this respect, it is important to note that the religious socialization experiences of our respondents preceded their actual switching or conversion to an evangelical congregation, which seems to allow us to make causal or at least chronological inferences in view of hypotheses 2 and 3. However, such firm orderings with regard to the possible effects of our respondents' religious orientation or socio-religious network are more difficult to establish, if at all.

\section{Method}

\section{Sample}

Our sample consists of 920 respondents coming from two different subpopulations: evangelicals and non-evangelicals. The evangelical respondents were gathered using a purposive sampling strategy. This was necessary for the following reason. In order to be able to properly address our research questions, it is crucial that our sample contains a sufficient number of converts and switchers to evangelical congregations. However, Dutch citizen registries do not contain information on religious affiliation 
nor are all evangelical congregations united under one denominational umbrella with a centralized membership registry. So, the only way of ensuring that our sample contains a sufficient number of converts and switchers is by focusing on thriving evangelical congregations that reported a recent growth in membership. Thus, we specifically looked for large thriving communities, serving around 1000 attendees or more in an average week, that self-identify as evangelical and that have mission statements in line with the six fundamental convictions of evangelicalism listed by McGrath (1995, 55-66): ascribing absolute authority to scripture; affirming the majesty of Jesus Christ; recognizing the work of the Holy Spirit; stressing the need for personal conversion; giving priority to evangelism and being committed to the Christian community. In the autumn of 2014, we had identified twelve large evangelical congregations and asked their leadership if they were willing to participate in our research by distributing a link to an online questionnaire among their members and/or attendees of 18 years or older. Eventually, six congregations located in various parts of the Netherlands, comprising a Nazarene church, two Baptist churches, an evangelical church mainly visited by people of Suriname and the Netherlands Antilles and two free evangelical churches with ties to Willow Creek Netherlands, agreed to participate and distributed the link among their members and/or attendees during the period November 2014-January 2015. This resulted in a total of 584 evangelicals who filled in our online questionnaire. Although such a relatively large sample of evangelicals is very unique for the Netherlands, we cannot tell to what extent this sample is representative for the total population of evangelicals in the Netherlands. Nevertheless, a comparison of the demographic profiles of the evangelicals in our sample and those who participated in the study of Stoffels (1990), until today one of the rare large-scale quantitative studies into the beliefs and values of evangelicals conducted in the Netherlands, hardly reveals any differences and even confirms the relatively high socioeconomic status of the evangelicals in our sample in terms of education and to a lesser extent of income. ${ }^{2}$

In order to be able to compare these evangelical respondents to mainline Christians and non-church members, we also distributed the link to our online questionnaire among a representative sample of the Dutch population. This sample was drawn in 2011 in view of the 'Religion in Dutch society 2011-2012' survey with previous waves of data collection in 1980, 1985, 1990, 1995, 2000, 2005 (Eisinga et al. 2012). In January 2015, a letter of invitation to participate in our research was sent to 918 respondents who had stated in 2011-2012 that they were willing to participate in future research. This resulted in a total of 336 respondents who filled in our online questionnaire. In view of this response rate of 36.6 percent, we checked to what extent this new sample is still comparable to the original sample. A comparison of general characteristics as education, marital status and income shows that this is not entirely the case. Chi square tests reveal that our new panel contains less lower educated and more higher educated respondents, more married respondents

\footnotetext{
2 The following congregations participated in this study: Maranatha Ministries in Amsterdam, Church of the Nazarene in Vlaardingen, Baptist Church "De Rank" in Utrecht, Free Baptist Community in Groningen, Free Evangelization in Zwolle and Evangelical Church "De Pijler" in Lelystad.
} 
and less singles as well as less respondents in the lower income category. Thus we decided to include education, marital status and income as control variables in our study next to gender and age. ${ }^{3}$

\section{Measures}

Data were gathered with the help of an online questionnaire comprising the following measures, already validated in previous studies.

\section{Religious Affiliation and Socio-Religious Network}

Respondents of the evangelical subpopulation were labeled evangelical if they consider themselves to be affiliated to one of the six participating congregations without at the same time being affiliated to another non-evangelical congregation. Respondents of the non-evangelical subpopulation could state their religious identity on a list comprising eleven Christian churches (cf. Te Grotenhuis and Scheepers 2001). Their answers were collapsed into five categories: Catholic, mainline Protestant, orthodox Protestant, evangelical and non-church member or none. ${ }^{4}$ In order to establish the respondents' juvenile religious identity, the respondents were asked if they belonged to a church when they were 12-15 years old, after which they again could indicate their religious identity on the same list of eleven Christian churches. On the basis of a comparison between the respondents' current and juvenile church membership we then constructed the variable "respondent switched to an evangelical congregation," which has six categories: stable non-church member, stable church member, Catholic to evangelical, mainline Protestant to evangelical, orthodox Protestant to evangelical and non-church member to evangelical.

Apart from inquiring after the church membership of the respondents themselves, the questionnaire also inquired after the church membership of their parents and partners. In this respect, all respondents were asked to indicate the present church membership of their father, mother and partner on the list of eleven Christian churches as well as the church membership of their father and mother when the respondents were 12-15 years old and the church membership of their partner when he or she was 12-15 years old. This information was then used to construct the variables "father/mother/partner switched to an evangelical congregation," which have two categories: father/mother/partner did not switch and father/mother/ partner switched to an evangelical congregation. In addition, the information on the church membership of the parents is also used to construct the variable "denominational incongruence father mother." This variable is based on a comparison between the church membership of the father and the mother when the respondent was

\footnotetext{
3 The dataset and more detailed documentation of this survey is available at: https://doi.org/10.17026/ dans-xdh-6gb3.

4 Mainline Protestants are members of the Protestant Church in the Netherlands, while orthodox Protestants are affiliated with one of the Reformed churches (cf. also note 1).
} 
12-15 years old and has two categories: denominational congruence father mother and denominational incongruence father mother.

\section{Religious Socialization}

Respondents could indicate if they were raised in a religious way and if their parents deemed a religious upbringing of their children important on a scale ranging from (1) not at all/very unimportant to (5) very religious/very important. In addition, respondents were also asked if prayer and Bible reading were regular activities in their homes on a scale ranging from (1) never to (7) several times a day. Finally, respondents were asked if they attended a public or a religious secondary school (cf. Vermeer, Janssen and De Hart 2011).

Next to these aspects of the religious upbringing the respondents enjoyed, their juvenile church attendance was measured with the help of the following question: "When you were 12-15 years old? How often did you attend religious services then?" This questions could be answered on a four point scale running from (1) almost never to (4) about once a week. In a similar way, the respondents were asked about the church attendance of their father and mother when the respondents were 12-15 years old.

\section{Religious Orientation}

The respondents' intrinsic and extrinsic religious orientation was assessed with the help of a shortened version of the religious orientation scale of Allport and Ross (cf. Hill and Hood 1999, 144-154). This instrument consists of fifteen items, seven items tapping an intrinsic religious orientation, like: "I try hard to carry my religion over into all my other dealings in life," and eight items tapping an extrinsic orientation, such as: "I pray chiefly because I have been taught to pray." Respondents could answers on a five point scale running from (1) strongly disagree to (5) strongly agree (For the intrinsic orientation Cronbach's alpha is .90 and the corrected item-total correlation ranges from .45 to .86 ; for the extrinsic orientation Cronbach's alpha is .79 and the corrected item-total correlation ranges from .21 to .59$){ }^{5}$

\section{Control Variables}

Education concerns the highest education completed and was collapsed into three categories: lower education (highest education is lower vocational school), middle education (from lower secondary school to secondary vocational school) and higher education (from $\mathrm{O}$ levels to $\mathrm{PhD}$ or doctorate). Marital status relates to: married, unmarried/single, living together, widow/widower and divorced. Income regards the gross monthly family income and runs from (1) less than 1000 euros to (9) more than 10.000 euros. With regard to income, missing values are replaced by the mean. Age is 2014 minus the respondent's year of birth.

\footnotetext{
5 Respondents could also choose a sixth option "never thought about it," which was recoded into the third option "disagree/agree".
} 
Table 1 Cross tabulation respondents' juvenile church membership by current church membership (\%)

\begin{tabular}{lllllll}
\hline Juvenile church membership & & & & & \\
\hline Current membership & Catholic & $\begin{array}{l}\text { Mainline } \\
\text { protestant }\end{array}$ & $\begin{array}{l}\text { Orthodox } \\
\text { protestant }\end{array}$ & Evangelical & None (N) & Total \\
\hline Catholic & 88.2 & 0.0 & 2.0 & 0.0 & 9.8 & 100 \\
Mainline protestant & 2.5 & 72.5 & 7.5 & 0.0 & 17.5 & $\begin{array}{l}(51) \\
100 \\
(40)\end{array}$ \\
Orthodox protestant & 0.0 & 0.0 & 90 & 0.0 & 10.0 & 100 \\
Evangelical & 2.6 & 26.9 & 24.4 & 20.4 & 25.7 & $\begin{array}{l}100 \\
(509)\end{array}$ \\
None & 19.9 & 8.8 & 2.3 & 0.0 & 69.9 & $\begin{array}{l}100 \\
(216)\end{array}$ \\
$\begin{array}{l}\text { Total } \\
\text { (N) }\end{array}$ & $\begin{array}{l}12.3 \\
(102)\end{array}$ & $\begin{array}{l}22.4 \\
(185)\end{array}$ & $\begin{array}{l}17.2 \\
(142)\end{array}$ & $\begin{array}{l}12.6 \\
(104)\end{array}$ & $\begin{array}{l}35.5 \\
(293)\end{array}$ & $\begin{array}{l}100 \\
(826)\end{array}$ \\
\hline
\end{tabular}

Cramer's V $=.43 ; p<.001$

\section{Results}

\section{Switching and Conversion}

First, we have a look at the changes in religious affiliation our data reveal and address our first research question. To this end, Table 1 compares the respondents' current church membership with their juvenile church membership, which immediately shows that there are a lot of switchers and converts among our evangelical respondents. We expected to find switchers and converts by purposively selecting thriving evangelical congregations and Table 1 now clearly reveals that our sampling strategy has been successful in this respect; i.e. the majority of our evangelical respondents indeed had a non-evangelical religious identity as youths. Among our evangelical respondents are 26.9 per cent mainline Protestant and 24.4 per cent orthodox Protestant switchers as well as 25.7 per cent secular converts with no prior religious identity. However, former Catholics are scarce among our evangelical respondents. No more than 2.6 per cent of these evangelicals is a former Catholic, which, in our opinion, confirms the cultural and theological distance between Catholicism and evangelicalism. Overall, these findings are in line with our first hypothesis. That is to say, among our evangelical respondents the largest percentage of switchers indeed have a mainline Protestant background, although the differences between the proportions of mainline and orthodox Protestant switchers and secular converts ${ }^{6}$ are actually very small.

\footnotetext{
${ }^{6}$ Included in this cross tabulation are 826 respondents of our initial sample of 920 respondents. This is for the most part due to the fact, that 75 respondents of the evangelical subpopulation stated to be currently affiliated to an evangelical congregation as well as to another non-evangelical congregation. These respondents were omitted from this and subsequent analyses
} 


\section{Bivariate Analyses}

In order to address our second research question, we first consider the bivariate associations between joining an evangelical congregation and the various factors concerning religious socialization, religious orientation and socio-religious network as well as the control variables. As mentioned already in the method section, the variable "respondent switched to an evangelical congregation" was constructed on the basis of the comparison between the respondents' current and juvenile church membership and initially had six categories: stable non-church member, stable church member, Catholic to evangelical, mainline Protestant to evangelical, orthodox Protestant to evangelical and non-church member to evangelical. However, the category Catholic to evangelical was omitted from these and subsequent analyses, because this category only has 13 cases (cf. also Table 1 ). ${ }^{7}$ As a result, Table 2 only displays the mean scores and percentages for the aforementioned factors for the five remaining categories as well as the related association coefficients (Eta or Cramer's V).

Now, as becomes clear from this table, most factors we distinguish in this study are indeed significantly related to joining an evangelical congregation. However, the strength of the associations is mostly weak to moderate and, consequently, the differences in mean scores and percentages between the stable non-church members, the stable church members and the switchers and converts are generally not very large. Still, a few factors stand out. The socialization experiences of having attended a religious school and being raised in a home where the Bible was frequently read are strongly related to joining an evangelical congregation, with respective association coefficients of .41 (Cramer's V) and .40 (Eta), while having an intrinsic religious orientation and the network factor of having a partner who also switched to an evangelical congregation are even very strongly related to joining an evangelical congregation, with respective association coefficients of .45 (Eta) and .58 (Cramer's V). All other factors are only weak to moderately related to joining an evangelical congregation, with the exception of being raised in a religiously heterogeneous family (denominational incongruence father mother) and income. These latter two factors are unrelated to joining an evangelical congregation, which already shows that hypothesis 3 does not hold for our sample. That is to say, being raised in a religiously heterogeneous family did not increase the likelihood of our respondents to join an evangelical congregation.

\footnotetext{
7 Furthermore, respondents who disaffiliated or who switched to another non-evangelical church were also excluded from these and subsequent analyses, which resulted in an additional loss of 76 cases. Thus included in the bivariate analyses are mostly around 737 (826 - 13 - 76) cases. A further reduction of cases is caused by the fact that several respondents skipped the questions concerning their religious orientation, which were included in the last part of our questionnaire; 144 missing cases for the intrinsic and extrinsic scale. Therefore, we used Chi square tests to compare the sample of respondents with scores on these scales with the overall sample of 920 respondents and found no statistical differences regarding such general characteristics as gender, age, education, marital status and income. This shows that the loss of respondents caused by missing cases on the religious orientations scales is random.
} 


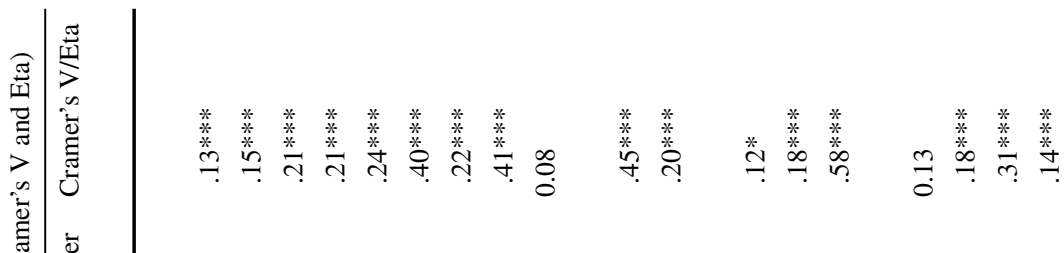

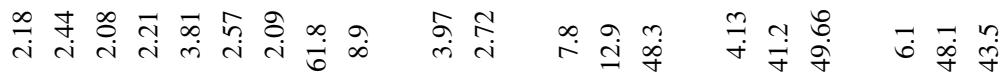

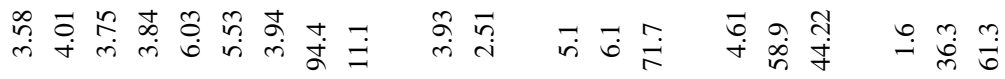

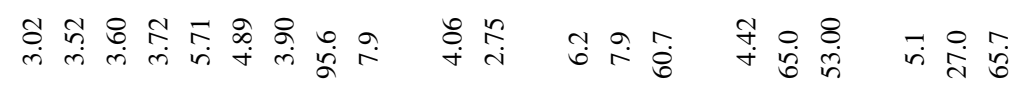

ले

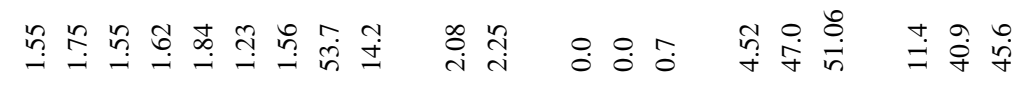

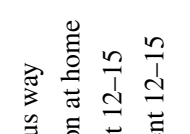
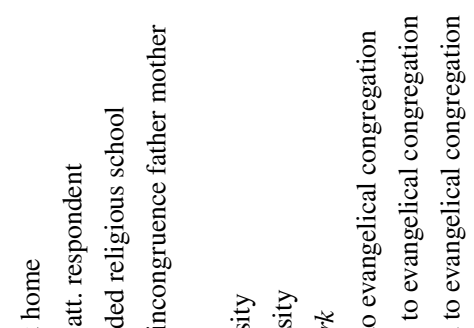

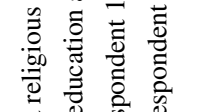

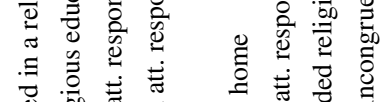

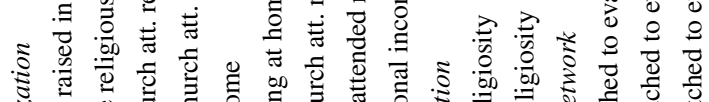




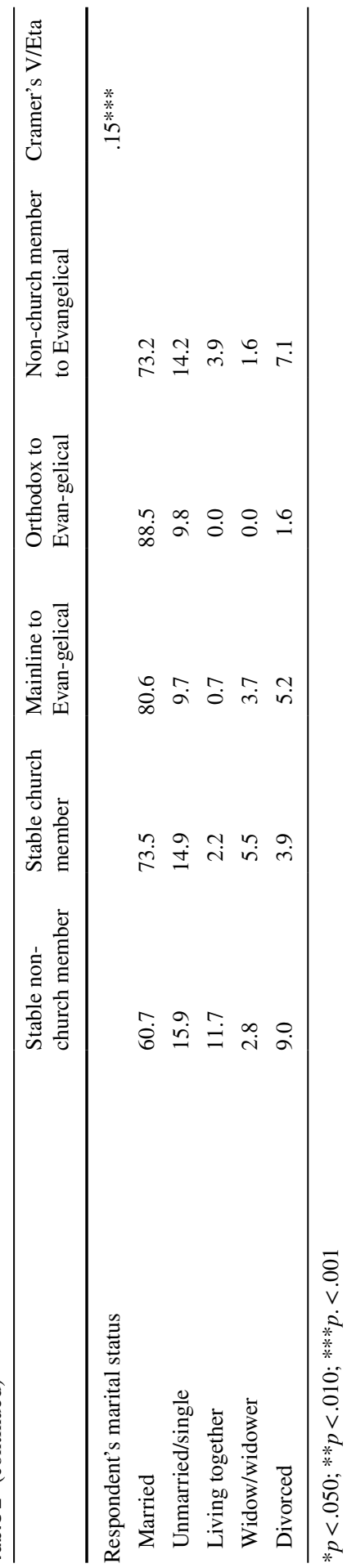




\section{Multivariate Analysis}

As a next step, we conducted a multivariate analysis in order to determine the most decisive factors for the switching or conversion of our respondents to an evangelical congregation. To do this, we conducted a multinomial logistic regression analysis to explore the relative effects of the various aspects of religious socialization, the respondents' religious orientation and socio-religious networks as well as the control variables on the probability of switching or converting to an evangelical congregation. Furthermore, for each group of switchers and converts we estimated two models. In a first model (M1) we only estimated the effects of socialization experiences. As mentioned already above, these experiences preceded the actual switching or conversion of our respondents and thus somewhat allow us to make causal or at least chronological claims in view of joining an evangelical congregation. In a second model (M2) we added the other factors as well as the control variables to the equation to see if possible socialization effects persist next to possible effects of the respondent's religious orientation or socio-religious network. Displayed in Table 3 are the odds ratios $(\operatorname{Exp}(\mathrm{B}))$ for these independent and control variables for respondents raised as a mainline Protestant, an orthodox Protestant or a non-church member to switch or convert to an evangelical congregation as compared to respondents who stayed in their church of origin. So we use stable church membership as our reference category and thus we compare staying versus switching or conversion. ${ }^{8}$

When it comes to the factors concerning religious socialization, Table 3 shows that having been raised in a family in which Bible reading was a regular practice is an important factor for the switching of mainline and orthodox Protestants and the conversion of non-church members. The higher the frequency of Bible reading in the family during their upbringing, the higher the likelihood that mainline and orthodox Protestants as well as non-church members join an evangelical congregation later in life. Furthermore, as regards the switching of mainline and orthodox Protestants, this positive effect of Bible reading in the family even persists when additional factors are also taken into account. However, Table 3 also shows additional negative socialization effects. Having been raised in a religious way reduces the likelihood of mainline

\footnotetext{
8 Since we found no statistically significant associations between the variable "respondent switched to an evangelical congregation" and "denominational incongruence father mother" as well as income, these variables were not included in the multivariate analysis (cf. Table 2). We also did not include the stable non-church members $(\mathrm{N}=151)$ in the analysis, because this would result in empty cells with regard to the variable "father/mother switched to an evangelical congregation" (cf. again Table 2). Thus it would be impossible to include this socio-religious network factor in the regression analysis if we would also include the stable non-church members. Since our main interest is a comparison of switching or conversion versus staying, we decided that the inclusion of socio-religious network factors is more important than the inclusion of the stable non-church members. In this respect, we also decided to only include the switching of the mother in the analysis in order to avoid the danger of multicollinearity, because the association between the variables "father switched to an evangelical congregation" and "mother switched to an evangelical congregation" is very strong (Cramer's $\mathrm{V}=.76 ; p<.001$ ). Finally, we did not include all dummy variables concerning marital status. This would again result in empty cells, since there are no orthodox Protestants switchers living together (cf. again Table 2), and the only significant differences we found concern the category married. Included, therefore, is only the dummy variable married.
} 


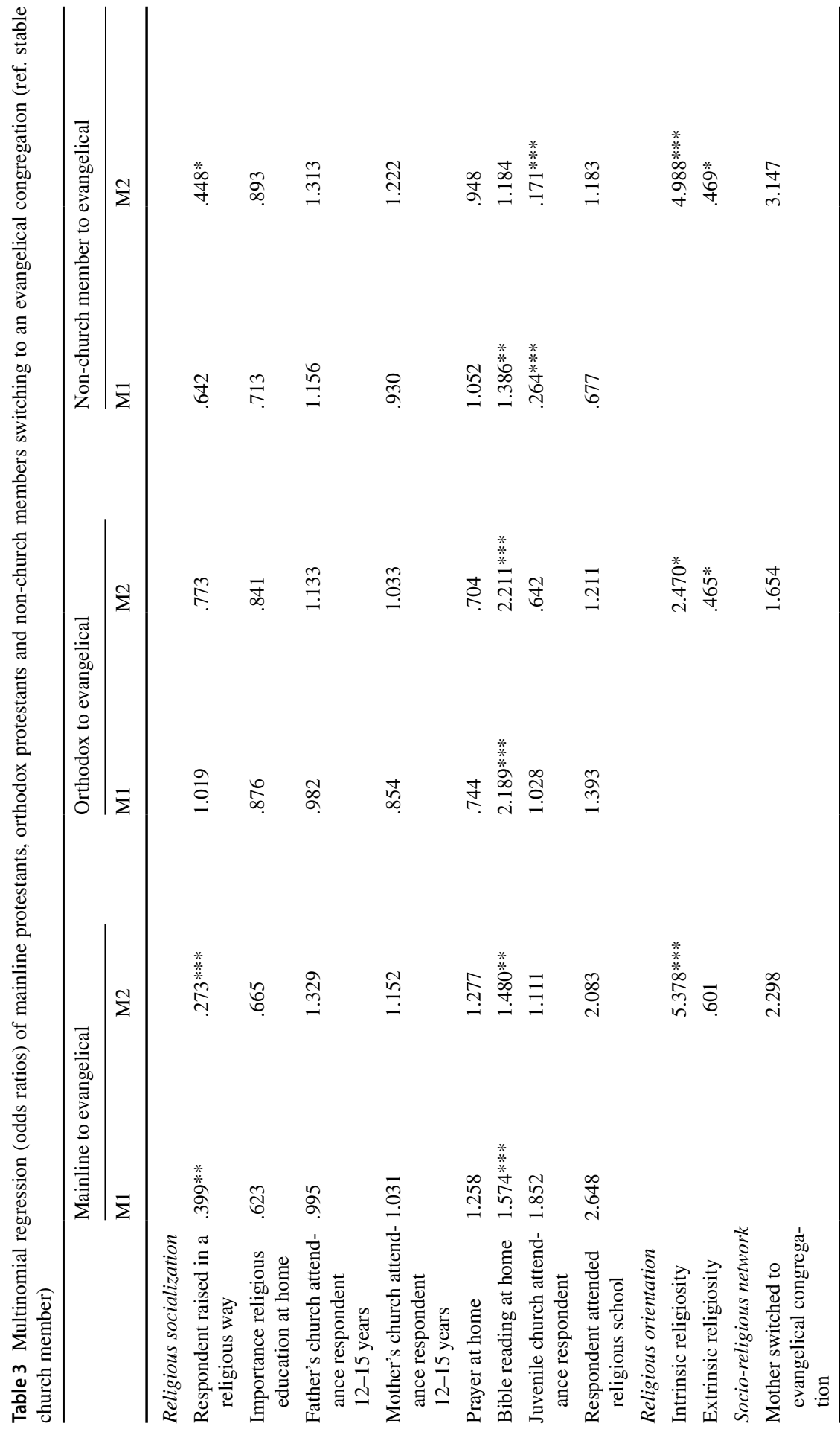




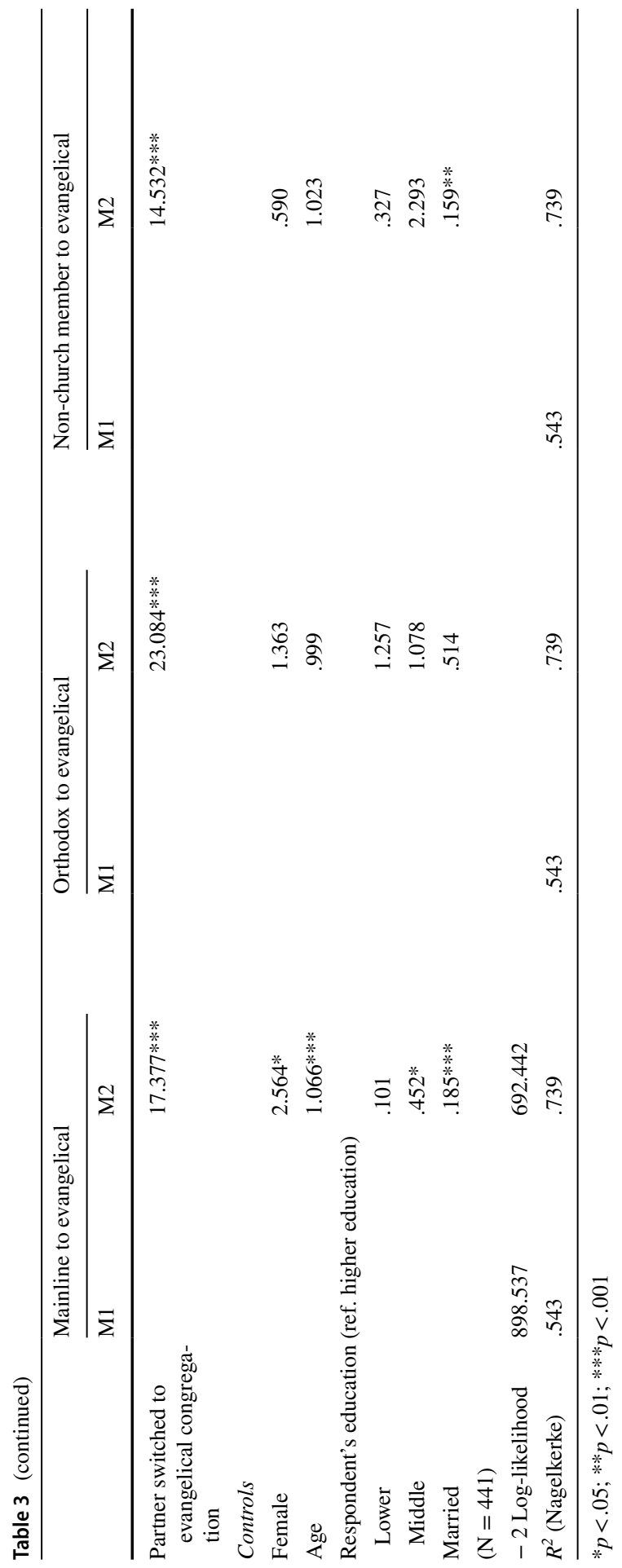


Protestants and non-church members to switch to an evangelical congregation later in life. In case of the mainline Protestant switchers, this negative effect is already present in the first model, while for non-church members it becomes significant in the second model. Finally, juvenile church attendance reduces the likelihood of non-church members joining an evangelical congregation. This negative effect is already present in the first model and even becomes stronger when other factors are added to the equation. As the second model shows, non-church members who attended church as youths are almost 6 (1/.171) times less likely to join an evangelical congregation later in life. Overall, these findings reveal several fairly strong socialization effects, but mostly not in accordance with our hypotheses. Bible reading in the family is a strong predictor for joining an evangelical congregation later in life for all three groups, which clearly supports hypothesis $2 \mathrm{e}$, but the negative effects of having been raised in a religious way by one's parents and juvenile church attendance clearly disconfirm hypotheses $2 \mathrm{a}$ and $2 \mathrm{f}$. In addition, the absence of any significant effects of the other socialization experiences we distinguish also disconfirms hypotheses $2 \mathrm{~b}, 2 \mathrm{c}, 2 \mathrm{~d}$ and $2 \mathrm{~g}$.

As regards the religious orientation of the switchers and secular converts, the results of the multivariate analysis clearly confirm hypothesis $4 \mathrm{a}$. As expected, the more mainline and orthodox Protestants and non-church members display an intrinsic religious orientation, the higher the likelihood that they will join an evangelical congregation. That is to say, if they move up one position on the intrinsic religious orientation scale from strongly disagree to strongly agree, mainline Protestants, orthodox Protestants and non-church members respectively are about 5.4 (5.378), 2.5 (2.470) and 5.0 (4.988) times more likely to join an evangelical congregation. Hypothesis $4 b$, in contrast, is only partially supported. Having an extrinsic religious orientation is indeed a negative predictor for joining an evangelical congregation, but this only goes for orthodox Protestants and non-church members. If these latter groups move up one position on the extrinsic religious orientation scale from strongly disagree to strongly agree, they respectively are about $2.2(1 / .465)$ and 2.1 (1/.469) times less likely to join an evangelical congregation. For mainline Protestants no such effect was found, which means that for this group hypothesis $4 \mathrm{~b}$ is disconfirmed.

With regard to the socio-religious network factors we distinguish, the multivariate analysis, first of all, disconfirms hypothesis 5. That is to say, having a mother who switched to an evangelical congregation does not increase the likelihood of mainline and orthodox Protestants or non-church members to join an evangelical congregation as well. However, the likelihood that members of these three groups join an evangelical congregation increases substantially if they have a partner who switched to an evangelical congregation, which is strong support for hypothesis 6. Mainline Protestants, orthodox Protestants and non-church members who have a partner who switched or converted to an evangelical congregation respectively are 17, 23 and 14 times more likely to join an evangelical congregation themselves than are mainline and orthodox Protestants and non-church members without such a partner. Thus our findings seem to point at a strong partner effect.

When it comes to the various control variables included in our study, the multivariate analysis shows that these variables are of lesser importance. Gender, age and education are only related to the switching of mainline Protestants. Female and older 
mainline Protestants are more likely to switch, while middle educated mainline Protestants are compared to higher educated mainline Protestants less likely to switch to an evangelical congregation. Finally, marriage also seems to inhibit switching and conversion as married mainline Protestants and non-church members respectively are $5.4(1 / .185)$ and $6.3(1 / .159)$ times less likely to join an evangelical congregation.

\section{Discussion}

Against the background of massive, religious disaffiliation in the country, evangelical church growth is a remarkable phenomenon in the Netherlands. A phenomenon we considered more closely in this paper by studying the switchers and converts to six thriving evangelical congregations of near megachurch size. More specifically, we addressed the following research questions: (1) What was the previous religious affiliation of the people who switched or converted to one of the six participating evangelical congregations? and (2) Which factors induced the switch or conversion to these congregations?

Our first question concerns the sources of evangelical church growth in the Netherlands and our results both confirm and challenge previous findings and theoretical insights. To begin with, the congregations we studied do not appeal to Catholics, which is clearly in line with the notion that people usually do not switch to very dissimilar churches (Iannaccone 1990; Need and De Graaf 2005; Sherkat and Wilson 1995). However, our finding that also orthodox Protestants switch to evangelical congregations runs counter to the idea initially made popular by Kelley (1972), that conservative churches especially grow at the expense of more mainline churches. The six congregations we studied appeal as much to mainline Protestants as to orthodox Protestants, which challenges the idea underlying the so-called "ecological niche" perspective that switchers are particularly looking for more theologically demanding and culturally distinctive churches (Sherkat 2001). Mainline Protestant switchers may indeed be looking for more demanding churches, but it is unlikely that this is the case with regard to the switching of orthodox Protestants. Actually, the respondents we labelled "orthodox Protestant" in this study are from Reformed churches, which are mostly considered strict and countercultural or culturally distinctive in the Netherlands. Hence, it is more appropriate to conclude, we propose, that these orthodox Protestant switchers are actually looking for the right mix between theological conservatism and cultural modernism; i.e. they may be looking for firm theological messages delivered with the help of contemporary styles of experiential worship (Klaver 2010, 394-396). A mixture of theological conservatism and cultural modernism Ellingson (2010) calls "selective sectarianism", which he considers an important cause of the success of megachurches in the US.

Another remarkable finding concerns the fact that 25 per cent of our evangelical respondents are previously unaffiliated converts. Thus, the growth of the six congregations that participated in our study seems to be both a matter of religious switching and of successfully reaching out to the unchurched. This finding seems to be in line with the second part of Kelley's (1972) original thesis, viz. that conservative church growth comes from mainline switching as well as from proselytism, while 
it disconfirms Bibby and Brinkerhoff's (1973; cf. also Bibby 1978) claim that the growth of conservative churches mainly comes from within the evangelical community itself. That is to say, especially people already familiar with evangelical culture join evangelical congregations; a phenomenon for which they coined the wellknown phrase "circulation of the saints."

However, when we turn to our second question and consider the factors that made our respondents switch or convert to an evangelical congregation, we may seriously doubt the importance of proselytism in this respect. Our multivariate analysis reveals an interesting socialization effect, which suggests that the non-church members joining an evangelical congregation are not really blank slates when it comes to religion. Like mainline and orthodox Protestants, non-church members are also more likely to join an evangelical congregation if they have been raised in a family in which the Bible was frequently read. It is true, that this effect disappears in the full model as a result of the addition of religious orientation and socio-religious network factors, but that leaves unhindered that Bible reading in the family is also positively related to the conversion of non-church members. This could indicate, we propose, that these secular converts are actually juvenile disaffiliates who were raised in religious homes. As Perrin, Kennedy and Miller (1997) found in their research into evangelical church growth in the US, although people may indicate no affiliation prior to their conversion to an evangelical congregation, they may still be raised in a certain religious tradition as a child. If this interpretation is correct, we are not so much dealing with secular converts but with juvenile dropouts who re-affiliated by joining an evangelical congregation! Thus contrary to what our findings seem to indicate at first glance, evangelical church growth in the Netherlands is probably more a matter of the "circulation of saints" than of proselytism.

Furthermore, as the results of our multivariate analysis also show, these 'saints' did not join an evangelical congregation all by themselves. Although they may also be motivated by strong intrinsic religious concerns, the role of the partner seems pivotal here. Our data do not allow us to determine the exact causal order in this respect and so we cannot tell if the switching or conversion of the respondent followed the switching or conversion of the partner or the other way round. Still, what we can say, is that given the strong association between the switching or conversion of the respondent and the switching of his/her partner, as demonstrated by our bivariate and multivariate analyses, social integration and support presumably is a key-factor when it comes to religious switching or conversion (cf. also Need and De Graaf 2005). That is to say, religious congruence between partners and experiencing social endorsement from one's partner are in all likelihood key-factors when joining an evangelical congregation next to the other factors we also identified; i.e. having an intrinsic religious orientation and having acquired sufficient religious human capital during one's upbringing.

In sum, our findings both confirm and challenge previous insights concerning religious switching and evangelical church growth. Our results again confirm the importance of socio-religious network factors and more specifically point out that partners are more important than parents in this respect. At the same time, our findings also challenge the idea that evangelical church growth is a matter of proselytism 
or successfully reaching out to the unchurched. As it turns out, evangelical church growth basically seems to be a matter of circulating, religious believers.

\section{Limitations}

When interpreting the above results, several limitations mostly relating to the purposive sampling strategy we used should be taken into account. We specifically targeted large, thriving evangelical congregations, because we had to have a sufficient number of switchers and converts in our sample to be able to address our research questions. Although our sampling strategy has been successful in this respect, it also limits our study in important ways. Our study is a case study of six thriving evangelical congregations and so we cannot generalize our findings to all Dutch evangelical congregations as such. In addition, not all evangelical congregations in the Netherlands are large and thriving and thus it might be the case that the testing of our hypotheses would yield somewhat other results if also members of small and not so thriving congregations were included in our sample. In this respect, we cannot rule out that a selection effect has affected our results. Finally, we must also be careful in drawing firm conclusions, because we do not know how representative our respondents are for the participating, thriving congregations nor what the participation rate for each congregation is. We could not determine the response rate for each congregation, because we did not have control over the number of questionnaires distributed to each. The link to our online questionnaire was distributed by the congregation's leadership, mostly via internal, digital newsletters, but the leadership did not allow us to take random samples from their membership lists.

Apart from the sampling strategy we used, another limitation concerns our use of one-shot, cross-sectional data. Since all data were gathered at one point in time we must be careful in making causal claims regarding the reasons why people joined an evangelical congregation. This even goes for the data concerning the socialization experiences of our respondents. Although we asked our respondents about their childhood experiences prior to their switching or conversion to an evangelical congregation, we cannot rule out that their answers are affected by a recall bias.

\section{Conclusion and Implications}

The six evangelical congregations that participated in this case study thus in part thrive, because they attract new members, or "saints," from the mainline and orthodox Protestant ranks as well as re-affiliates. They do not, however, attract Catholics nor do they really seem to attract much secular converts with no prior religious background. In this way, our findings primarily reflect a reshuffling of the more conservative part of Dutch Protestantism where both certain mainline and orthodox Protestants, endorsed by and in line with their partners, are looking for alternative congregations. Overall, these findings are consistent with a more general trend in the Dutch religious landscape. In the Netherlands religious disaffiliation is massive among liberal believers, while those who remain loyal to their congregations 
become more committed and orthodox. Especially Catholics, traditionally the most liberal and lenient believers in the Netherlands, are nowadays filling the ranks of the religiously non-affiliated, while Protestants are more likely to consider alternatives like, for instance, evangelical congregations (De Hart 2014, 30-68). But if the success of these evangelical congregations in this way is really the result of a "conservative reshuffling," their potential to grow is at the same time limited. In the Netherlands, as well as in several other Western countries, the proportion of religious people is shrinking over time, which simply limits the potential number of switchers and re-affiliates in the near future. In all likelihood, then, thriving evangelical congregations will remain an exception in secular societies like the Netherlands.

Still, given the aforementioned limitations of this study, further research is needed to make more reliable and valid inferences regarding the future of evangelical congregations in a Western country like the Netherlands. In this respect, it may be worthwhile to study a broader sample of evangelicals than only those visiting a thriving congregation, while more in depth comparative studies on the basis of larger samples of mainline Protestants and Catholics may also help to uncover the specific appeal of evangelicalism in such a secular context. Finally, it is also interesting to go beyond the congregational model and to study, for instance, if, and to what extent, evangelicals, or Christians more broadly, nowadays congregate in other more virtual ways than physically visiting a church; a phenomenon which may have even been spurred recently by the corona crisis. Continued research is needed, therefore, to better understand the dynamics of the religious landscape evangelicals find themselves in.

Open Access This article is licensed under a Creative Commons Attribution 4.0 International License, which permits use, sharing, adaptation, distribution and reproduction in any medium or format, as long as you give appropriate credit to the original author(s) and the source, provide a link to the Creative Commons licence, and indicate if changes were made. The images or other third party material in this article are included in the article's Creative Commons licence, unless indicated otherwise in a credit line to the material. If material is not included in the article's Creative Commons licence and your intended use is not permitted by statutory regulation or exceeds the permitted use, you will need to obtain permission directly from the copyright holder. To view a copy of this licence, visit http://creativecommons.org/licen ses/by/4.0/.

\section{References}

Batson, C.Daniel, and W.Larry Ventis. 1982. The Religious Experience. A Social-Psychological Perspective. New York: Oxford University Press.

Becker, Jos, and Joep de Hart. 2006. Godsdienstige veranderingen in Nederland. Verschuivingen in de banden met de kerken en de christelijke traditie. Den Haag: Sociaal en Cultureel Planbureau.

Bernts, Ton, Gert de Jong, and Hasan Yar. 2006. Een religieuze atlas van Nederland. In Geloven in het publieke domein. Verkenning van een dubbele transformatie, ed. Wim van de Donk, Petra Jonkers, Gerrit Kronjee, and Rob Plum, 89-138. Amsterdam: Amsterdam University Press.

Bernts, Ton, and Joantine Berghuijs. 2016. God in Nederland 1966-2015. Utrecht: Ten Have.

Bibby, Reginald W. 1978. Why Conservative Churches Really Are Growing: Kelley Revisited. Journal for the Scientific Study of Religion 17 (2): 129-137.

Bibby, Reginald W., and Merlin B. Brinkerhoff. 1973. The Circulation of the Saints: A Study of People Who Join Conservative Churches. Journal for the Scientific Study of Religion 12 (3): 273-283. 
Bibby, Reginald W. 1999. On Boundaries, Gates, and Circulating Saints: A Longitudinal Look at Loyalty and Loss. Review of Religious Research 41 (2): 149-164.

Boersema, Pieter. 2005. The Evangelical Movement in the Netherlands. New Wine in New Wineskins? In The Dutch and their Gods. Secularization and Transformation of Religion in the Netherlands since 1950, ed. Erik Sengers, 163-179. Hilversum: Verloren.

Chorpade, Jai, James R. Lackritz, and Rebecca Moore. 2010. Intrinsic Religious Orientation: The Conservative Christian Connection. International Journal for the Psychology of Religion 20 (3): 201-218.

De Hart, Joep. 2014. Geloven binnen en buiten verband. Godsdienstige ontwikkelingen in Nederland. Den Haag: Sociaal en Cultureel Planbureau.

De Hart, Joep, and Pepijn van Houwelingen. 2018. Christenen in Nederland. Kerkelijke deelname en christelijke gelovigheid. Den Haag: Sociaal en Cultureel Planbureau.

Eisinga, Rob, Gerbert Kraaykamp, Peer Scheepers, and Paula Thijs. 2012. Religion in Dutch Society 2011-2012. Documentation on a National Survey on Religious and Secular Attitudes and Behavior. Amsterdam: Pallas Publications.

Ellingson, Stephen. 2010. New Research on Megachurches. Non-denominationalism and Sectarianism. In The New Blackwell Companion to the Sociology of Religion, ed. Bryan S. Turner, 247-266. Oxford: Wiley-Blackwell.

Hadaway, C.Kirk. 1980. Denominational Switching and Religiosity. Review of Religious Research 21 (4): 451-461.

Hadaway, C.Kirk, and Penny L. Marler. 1993. All in the Family: Religious Mobility in America. Review of Religious Research 35 (2): 97-116.

Hak, Durk. 2006. Het evangelikalisme als toekomst van een 'illusie'? Het evolutionistische perspectief. Religie en Samenleving 1 (2): 95-108.

Hill, Peter C., and Ralph W. Hood. 1999. Measures of Religiosity. Birmingham: Religious Education Press.

Iannaccone, Laurence R. 1990. Religious Practice: A Human Capital Approach. Journal for the Scientific Study of Religion 29 (3): 297-314.

Kelley, Dean M. 1972. Why Conservative Churches are Growing. A Study in Sociology of Religion. New York: Harper and Row.

Kelley, Jonathan, and Nan Dirk De Graaf. 1997. National Context, Parental Socialization, and Religious Belief: Results From 15 Nations. American Sociological Review 62 (4): 639-659.

Klaver, Miranda. 2010. Hartstochtelijk protestantisme. Bronnen en kenmerken van de evangelische beweging in Nederland. Tijdschrift voor Theologie 50 (4): 385-400.

Kregting, Joris, Peer Scheepers, Paul Vermeer, and Chris Hermans. 2018. Why God Has Left the Netherlands: Explanations for the Decline of Institutional Christianity in the Netherlands between 1966 and 2015. Journal for the Scientific Study of Religion 57 (1): 58-79.

Loveland, Matthew T. 2003. Religious Switching: Preference Development, Maintenance, and Change. Journal for the Scientific Study of Religion 42 (1): 147-158.

McGrath, Alistair. 1995. Evangelicalism and the Future of Christianity. Downers Grove: Intervarsity Press.

Myers, Scott M. 1996. An Interactive Model of Religiosity Inheritance: The Importance of Family Context. American Sociological Review 61 (5): 858-866.

Need, Ariana, and Nan Dirk de Graaf. 2005. Zich bekeren en wisselen van kerkgenootschap in Nederland. Mens \& Maatschappij 80 (4): 288-304.

Perrin, Robin D., Paul Kennedy, and Donald E. Miller. 1997. Examining the Sources of Conservative Chruch Growth: Where are the New Evangelical Movements Getting Their Numbers? Journal for the Scientific Study of Religion 36 (1): 71-80.

Pollack, Detlef, and Gergely Rosta. 2015. Religion in der Moderne. Ein internationaler Vergleich. Frankfurt/New York: Campus Verlag.

Putnam, Robert D., and David M. Campbell. 2010. American Grace. How Religion Divides and Unites us. New York: Simon and Schuster.

Reitsma, Jan, Ben Pelzer, Peer Scheepers, and H. Hans Schilderman. 2012. Believing and belonging in Europe 1981-2007: Comparisons of Longitudinal Trends and Determinants. European Societies 14 (4): 611-632.

Sägesser, Caroline, Jan Nelis, Jean-Pierre Schreiber, and Cécile Vanderpelen-Diagre. 2018. Religion and Secularism in the European Union. Bruxelles: Université Libre de Bruxelles. 
Sandomirsky, Sharon, and John Wilson. 1990. Processes of Disaffiliation: Religious Mobility Among Men and Women. Social Forces 68 (4): 1211-1229.

Sherkat, Darren E. 1991. Leaving the Faith: Testing Theories of Religious Switching Using Survival Models. Social Science Research 20 (2): 171-187.

Sherkat, Darren E. 2001. Tracking the Restructuring of American Religion: Religious Affiliation and Patterns of Religious Mobility. Social Forces 79 (4): 1459-1493.

Sherkat, Darren E., and John Wilson. 1995. Preferences, Constraints, and Choices in Religious Markets: An Examination of Religious Switching and Apostasy. Social Forces 73 (3): 993-1026.

Stark, Rodney. 2015. The Triump of Faith. Why the World Is More Religious Than Ever. Delaware: ISI Books.

Stoffels, Hyme. 1990. Wandelen in het licht. Waarden, geloofsovertuigingen en sociale posities van Nederlandse evangelischen. Kampen: Kok.

Manfred, Te Grotenhuis, and Peer Scheepers. 2001. Churches in Dutch, Causes of Disaffiliation in the Netherlands 1937-1995. Journal for the Scientific Study of Religion 40 (4): 591-606.

Vermeer, Paul, Jacques Janssen, and Joep de Hart. 2011. Religious Socialization and Church Attendance in the Netherlands Between 1983 and 2007: A Panel Study. Social Compass 58 (3): 373-392.

Vermeer, Paul, and Peer Scheepers. 2018. Comparing Political Attitudes of Evangelicals with the Attitudes of Mainline Christians and Non-Church Members in the Netherlands. Politics and Religion 11 (1): 116-145.

Publisher's Note Springer Nature remains neutral with regard to jurisdictional claims in published maps and institutional affiliations.

\section{Affiliations}

\section{Paul Vermeer $^{1}$ (D) $\cdot$ Peer Scheepers ${ }^{2}$}

Paul Vermeer

p.vermeer@ftr.ru.nl

Peer Scheepers

p.scheepers@maw.ru.nl

1 Faculty of Philosophy, Theology and Religious Studies, Radboud University, PO Box 9103, 6500 HD Nijmegen, The Netherlands

2 Faculty of Social Sciences, Radboud University, PO Box 9104, 6500 HE Nijmegen, The Netherlands 